\title{
The 2012 dengue outbreak in Madeira: exploring the
}

\section{origins}

A Wilder-Smith (anneliesws@gmail.com) ${ }^{1,2}$, M Quam $^{1}$, 0 Sessions 3 , J Rocklov ${ }^{1}$, J Liu-Helmersson ${ }^{1}$, L Franco ${ }^{4}, K_{\text {Khan }}^{5}$

1. Department of Public Health and Clinical Medicine, Epidemiology and Global Health, Umeå University, Sweden

2. Lee Kong Chian School of Medicine, Nanyang Technological University, Singapore

3. Duke-NUS Graduate Medical School, Emerging Infectious Diseases Programme, Singapore

4. Arbovirus and imported viral disease laboratory, Instituto de Salud Carlos III, Madrid, Spain

5. University of Toronto, Division of Infectious Diseases, Canada

Citation style for this article:

Wilder-Smith A, Quam M, Sessions O, Rocklov J, Liu-Helmersson J, Franco L, Khan K. The 2012 dengue outbreak in Madeira: exploring the origins . Euro Surveill. 2014;19(8):pii=20718. Available online: http://www.eurosurveillance.org/ViewArticle.aspx?Articleld=20718

In 2012, Madeira reported its first major outbreak of dengue. To identify the origin of the imported dengue virus, we investigated the interconnectivity via air travel between dengue-endemic countries and Madeira, and compared available sequences against GenBank. There were 22,948 air travellers to Madeira in 2012 , originating from twenty-nine dengue-endemic countries; $89.6 \%$ of these international travellers originated from Venezuela and Brazil. We developed an importation index that takes into account both travel volume and the extent of dengue incidence in the country of origin. Venezuela and Brazil had by far the highest importation indices compared with all other dengue-endemic countries. The importation index for Venezuela was twice as high as that for Brazil. When taking into account seasonality in the months preceding the onset of the Madeira outbreak, this index was even seven times higher for Venezuela than for Brazil during this time. Dengue sequencing shows that the virus responsible for the Madeira outbreak was most closely related to viruses circulating in Venezuela, Brazil and Columbia. Applying the importation index, Venezuela was identified as the most likely origin of importation of dengue virus via travellers to Madeira. We propose that the importation index is a new additional tool that can help to identify and anticipate the most probable country of origin for importation of dengue into currently non-endemic countries.

\section{Introduction}

Dengue is an important arboviral disease, endemic mainly in the tropics and sub-tropics. Over $50 \%$ of the world's population lives in areas where there is a risk of contracting the disease [1]. Dengue is also the most rapidly spreading mosquito-borne viral disease in the world. In the past 50 years, the incidence of dengue has increased 30 -fold with geographic expansion to new countries [2]. An estimated 50 million to 100 million dengue infections occur annually according to the World Health Organization (WHO) [2]. Using consensus and modelling approaches, recent estimates of the burden of dengue are as high as 390 million infections per year [3].

The reasons for the resurgence and geographic expansion of dengue are complex, and include factors such as climate change, virus evolution, deteriorating vector control, and societal changes [4]. Population growth associated with rapid uncontrolled urbanisation is likely to be the main factor that has driven the rapid amplification of dengue in many endemic countries in recent decades [5]. One of the primary factors behind the geographic spread to non-endemic areas is the introduction of infected Aedes mosquitoes by shipping [6] and importation of dengue virus via viraemic travellers using through air travel $[1,7]$.

Imported dengue via travellers to currently nonendemic countries has increased steadily in recent decades, as reported by GeoSentinel, a worldwide network of travel medicine providers $[8,9]$. Dengue is the top cause of febrile illnesses in international travellers returning from south-east Asia [10]. Australia has seen a dramatic rise in the number of dengue cases caused by returning travellers, particularly from south-east Asia, with an increase of approximately $350 \%$ between 2004-2007 and 2008-2011 [11,12]. In Europe, various countries have also reported increased numbers of dengue in returning travellers to Europe [13-16].

While imported dengue cases to the United States have resulted in small but contained dengue clusters for many years [17-21], no autochthonous cases were reported in Europe until 2010, when two cases were reported in southern France, followed later that year by cases in Croatia [22,23]. In 2012 came the report of the first major outbreak of dengue in Europe [24] since the 1926-1928 outbreak in Greece [25]. This outbreak occurred in the autonomous region of Madeira, Portugal. Madeira is an archipelago in the Atlantic on the same latitude as the north coast of Africa [26]. The main vector for dengue, Aedes aegypti, is reported to 
have been introduced to Madeira in 2005 [27] and has been able to establish itself thanks to Madeira's subtropical climate.

The outbreak of dengue in Madeira evolved rapidly from its onset on 3 October 2012 and had resulted in over 2,100 cases by March 2013, with 78 cases introduced into 13 other European countries via travellers departing Madeira [24], and was due to dengue virus serotype 1 (DENV-1) [27].

Information on air traffic can be used to predict the risks of vector-borne disease importation [28]. A project known as BioDiaspora was developed to evaluate the probable pathways of international dissemination of infectious diseases via the global airline transportation network [29]. BioDiaspora assesses the ways in which countries around the globe are connected through international travel and consequently how they share risks associated with infectious diseases [30].

In this study, we attempted to determine the most likely country of origin of the dengue virus responsible for the 2012 Madeira epidemic. If we assume that dengue was introduced through viraemic travellers, the risk of importation of dengue is presumably a function of dengue virus activity in the country of origin and the volume of travellers from there to Madeira. To identify the origin of the imported dengue virus, we investigated the interconnectivity via air travel between dengueendemic countries and Madeira. Properly-annotated sequence data for dengue can help to track the spread of dengue, and, in particular, help to identify the probable origin of virus importation. We therefore also compared the available sequence information from the Madeira epidemic to other sequences available in GenBank.

\section{Methods}

To describe global air travel patterns to Madeira from dengue-endemic countries, we analysed worldwide full-route flight itinerary data, taking into consideration all traveller flight connections, from the International Air Transport Association (IATA) between 1 January and 31 December 2012, as collated by BioDiaspora. We identified dengue-endemic countries from the global map created by Brady et al. and selected countries where dengue endemicity has been well documented (complete, good and moderate consensus evidence) [31]. Countries such as the US, Argentina, Australia and China, where dengue activity is limited to very small areas within the country, were excluded. We examined the cities and countries where individuals initiated travel and had a final destination in Madeira. This included direct and indirect flights to Madeira. We quantified the total number of travellers arriving from individual dengue-endemic countries in Madeira in 2012 and created a map depicting the volume of travellers from individual cities within those countries. We also quantified the volume of arriving travellers in monthly intervals for the countries with the highest travel volume to Madeira.

We obtained the 2012 annual incidence rate (IR) for dengue per 100,000 population from WHO regional websites or as specified in the Table [32-36].

The risk of importation of dengue depends on (i) dengue activity in the country of origin and (ii) the volume of travellers from the country of origin to Madeira.

\section{TABLE}

Annual number of air travellers to Madeira, annual incidence rate of dengue infection in the country of embarkation and annual importation index into Madeira in 2012

\begin{tabular}{|c|c|c|c|}
\hline $\begin{array}{l}\text { Country of } \\
\text { embarkation }\end{array}$ & $\begin{array}{r}\text { Traveller } \\
\text { volume } \\
(\mathrm{TV})^{\mathrm{a}}\end{array}$ & $\begin{array}{r}\text { Annual } \\
\text { incidence } \\
\text { rate (IR) }\end{array}$ & $\begin{array}{c}\text { Annual } \\
\text { importation } \\
\text { index (ID) }\end{array}$ \\
\hline Venezuela & 15,884 & 174.86 & 27.77 \\
\hline Brazil & 4,676 & 295.33 & 13.81 \\
\hline Thailand ${ }^{\mathrm{d}}$ & 214 & 116.35 & 0.25 \\
\hline Aruba & 11 & 653.92 & 0.07 \\
\hline Philippines $^{d}$ & 19 & 172.15 & 0.03 \\
\hline Costa Rica & 20 & 149.11 & 0.03 \\
\hline Colombia & 4 & 487.46 & 0.02 \\
\hline Panama & 9 & 215.18 & 0.02 \\
\hline Singapore $^{d}$ & 3 & 585.39 & 0.017 \\
\hline Mexico & 4 & 345.6 & 0.013 \\
\hline Ecuador & 37 & 37.36 & 0.01 \\
\hline Paraguay & 17 & 86.04 & 0.01 \\
\hline Puerto Rico & 6 & 123.39 & 0.007 \\
\hline Sri Lanka ${ }^{d}$ & 2 & 206.95 & 0.004 \\
\hline Vietnam $^{\mathrm{d}}$ & 4 & 84.81 & 0.003 \\
\hline Guatemala & 3 & 81.69 & 0.002 \\
\hline Indiad & 9 & 4.17 & 0.0004 \\
\hline Bahamas & 4 & 1.46 & 0.00006 \\
\hline Angola & 1,281 & NA & NA \\
\hline Cape Verde & 352 & NA & NA \\
\hline Senegal & 122 & NA & NA \\
\hline Mozambique & 111 & NA & NA \\
\hline Reunion & 53 & NA & NA \\
\hline Nigeria & 33 & NA & NA \\
\hline Guinea-Bissau & 26 & NA & NA \\
\hline Cameroon & 15 & NA & NA \\
\hline Mauritius & 13 & NA & NA \\
\hline Ghana & 12 & NA & NA \\
\hline Madagascar & 4 & NA & NA \\
\hline
\end{tabular}

NA: not available.

Annual number of travellers to Madeira.

b Annual incidence per 100,000 inhabitants using World Health Organization (WHO) and Regional Office websites [32-35]. WHO Regional Office for Africa dengue incidence by country was not available at the regional level.

Annual importation index units in traveller incident cases per year. The formula used is ID $=I R \times T V$.

d Where only incidence was available, 2012 population was taken from [36]. 
Based on these two parameters, we calculated countryspecific risk indices referred to as importation indices. A higher importation index indicates a higher product of dengue activity and air travel volume to Madeira from a particular dengue-endemic country.

We used the following formula for the importation index for a given country:

$I D=I R \times T V$

where ID is the importation index, IR is the incidence rate of dengue in the country of origin and TV is traveller volume (the total number of annual air travellers from a given country to Madeira).

We then selected the two countries with the highest importation index to assess seasonal trends in travel. To observe the seasonality of this importation index, we obtained the monthly and weekly incidences of reported dengue cases for 2012 from online governmental surveillance portals for these two countries $[37,38]$. Using 2012 traveller volume by month into Madeira, we generated and compared the importation index scaled by month to observe the likelihood that one or both countries may have been the source of the dengue-viraemic traveller(s) during the months that preceded the onset of the outbreak.
Multiple sequence alignment of the Madeira dengue virus serotype 1 sequence (GenBank: KC248375.1) to other DENV-1 sequences deposited in GenBank was carried out using a fast Fourier transform in MAFFT, a multiple sequence alignment programme [39]. The maximum-likelihood phylogenetic tree was inferred from the sequence alignment using RAxML [40]. The robustness of the maximum-likelihood tree was assessed by 1000 maximum-likelihood bootstrap replications. The maximum-likelihood tree was visualised and produced using FigTree v1.4.0 [41].

\section{Results}

\section{Connectivity to Madeira via air travel}

There were 22,948 air travellers to Madeira in 2012, originating from twenty-nine dengue-endemic countries; $89.6 \%$ of these international travellers originated from Venezuela and Brazil (Table). The number of air travellers from Venezuela to Madeira was 15,884, almost four times higher than the 4,676 travellers from Brazil. Most of the air travellers from Venezuela boarded in Caracas, whereas in Brazil most travellers boarded in Sao Paulo and Rio de Janeiro.

Figure 1 shows a map of the world with air traffic intensity between dengue-endemic countries and Madeira

\section{FIGURE 1}

Map of air travel volume by country and city from dengue-endemic countries to Madeira, 2012

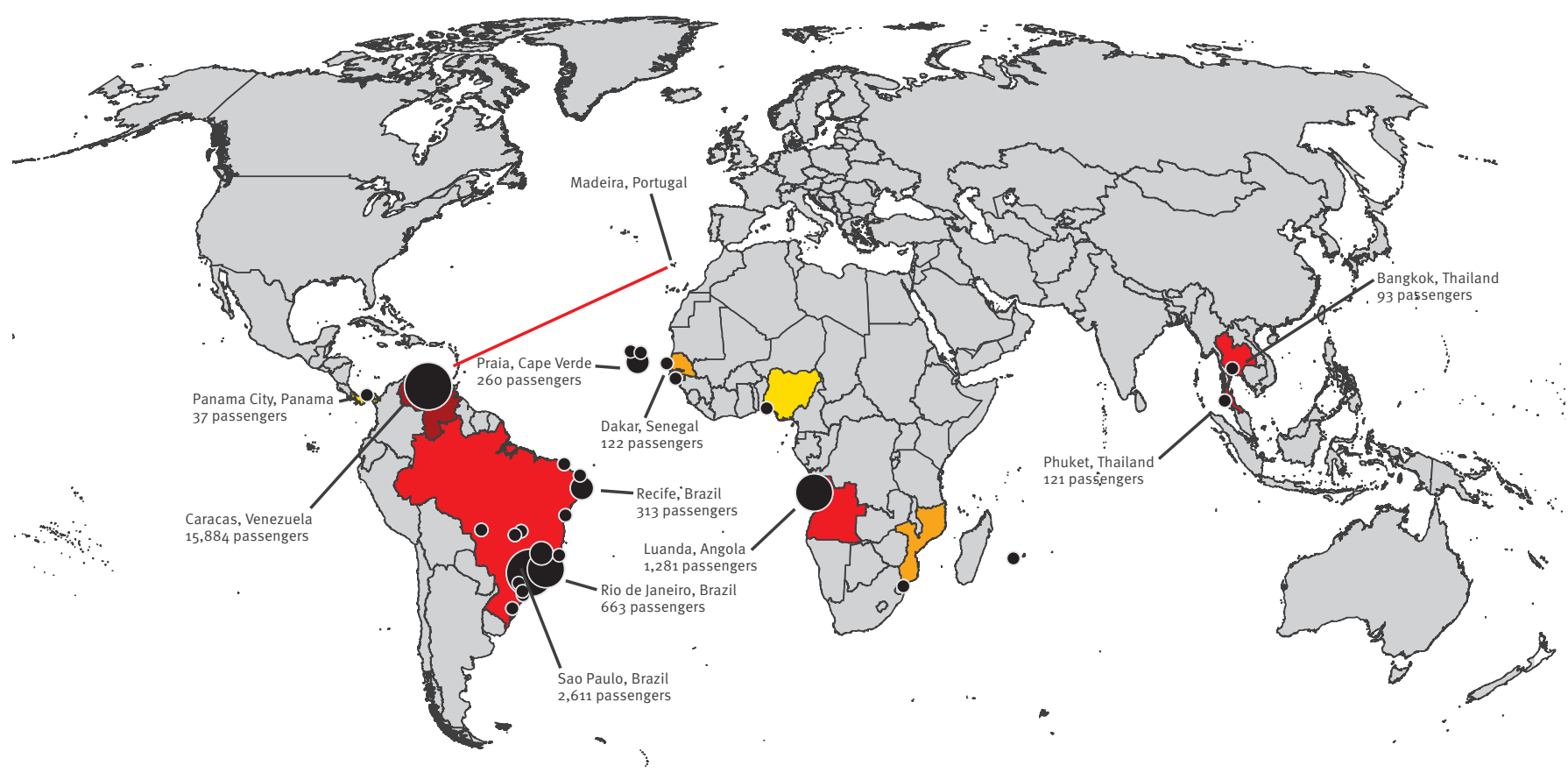

Direct flight
Travel volume by country

$$
\begin{aligned}
& \square<25 \\
& \square \text { 26-100 } \\
& \square \text { 101-200 } \\
& \square \\
& 201-5,000 \\
& 5,001-20,000
\end{aligned}
$$

Travel volume by city

$$
\begin{aligned}
& 25-200 \\
& 201-500 \\
& 501-2,500 \\
& 2,501-20,000
\end{aligned}
$$


in 2012. Only Venezuela has direct flights to Madeira, originating in Caracas.

Using the formula above, we calculated the annual importation index for 2012 to be $27.77((174.86 / 100,000)$ $\times 15,884)$ and $13.81((295.33 / 100,000) \times 4,676)$ for Venezuela and Brazil respectively. The ratio of the IDs suggests a dengue importation risk from Venezuela that was 2.01 times higher than from Brazil. We calculated 2012 IDs for all other countries as summarised in the Table.

Figure 2 shows the importation indices generated by month for Venezuela and Brazil, using reported cases in 2012 as well as 2012 IATA travel volume by month. Both Brazil and Venezuela have a seasonal peak of interconnectivity with Madeira during the month of July, but have distinctly different seasonal peaks of dengue activity. The monthly-scaled importation index for Brazil, which combined both factors, reaches its annual peak of 3.29 in April, whereas Venezuela reaches a much higher peak, 6.58, in August. Using the monthly index for the months of July, August and September, the index reflects an importation index averaging up to seven times greater for Venezuela than for Brazil.

\section{Dengue sequencing}

The 494 base pair sequence used for this analysis indicates that the Madeira virus is most closely related to a DENV-1 strain within Genotype V from South America (Figure 3), particularly those previously sequenced from Colombia (GQ868570; 452/454 identities), Venezuela (JN819415; 450/454 identities) and Brazil (JN713897; $450 / 454$ identities).

\section{FIGURE 2}

Monthly importation index for dengue virus by travellers to Madeira from Venezuela and Brazil, January-December 2012

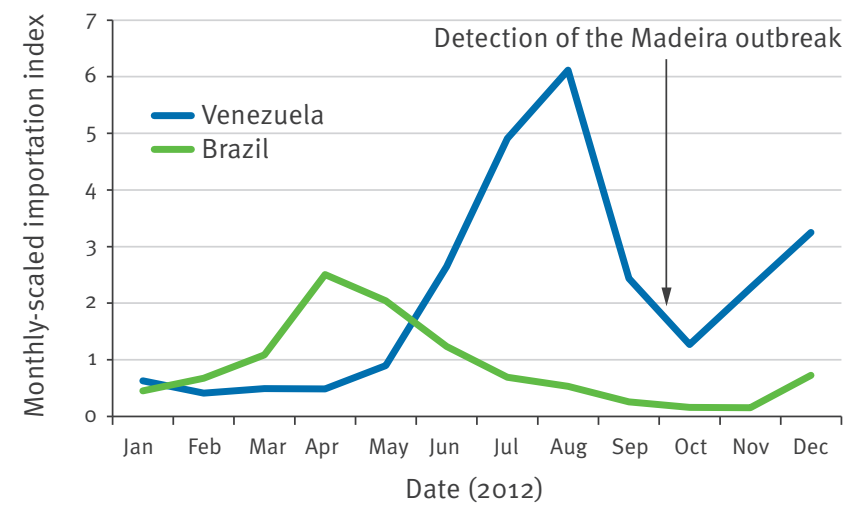

The dengue outbreak in Madeira was detected in October and first cases were determined to have happened end September [27].

$\mathrm{Y}$ axis shows importation index units in traveller incident cases per month. Based on 2012 International Air Transport Association (IATA) travel volume [29], and monthly country incidence obtained from national surveillance systems reports for Venezuela and Brazil $[37,38]$.

\section{Discussion}

We attempted to explore the origin of importation of dengue into Madeira that resulted in the massive outbreak in 2012, taking into account air travel patterns and dengue sequencing.

In principle, importation of dengue can occur via infected mosquitoes or via viraemic travellers. Importation of Aedes mosquitoes via the shipping and cargo industry is well established [42], and this was the most likely route of the introduction of Aedes mosquitoes to Madeira in 2005. Aedes populations remained established in Madeira due to the favourable climate, and so the conditions exist for a dengue outbreak to occur if the virus is imported $[43,44]$. It is also possible that dengue virus in infected mosquitoes may survive the long journey due to transovarial transmission. However, data on mosquito populations on cargo and passenger ships are difficult to obtain, as are data on the extent of connectivity to Madeira. Furthermore, the probability of importation of dengue via viraemic travellers is thought to be much higher than through dengue virus importation in mosquitoes $[1,6,45,46]$. The duration of viraemia is 5 to 7 days [47], and too short to last the journey on cruise ships from most well-documented endemic countries in Asia or the Americas to Madeira. Therefore, we conclude, modern rapid transportation via aeroplane is the most likely source of importation of dengue virus between countries.

Although south-east Asia carries the main burden of dengue worldwide [47], Asia is unlikely to be the origin of the importation of dengue to Madeira, because of much lower interconnectivity to this island. Indeed, even high-risk countries such as Thailand had a very low importation index. Based on the importation index, our findings show that Venezuela is by far the most likely origin of the Madeira outbreak. The importation index was almost two times higher than for Brazil, the country with the second highest interconnectivity with Madeira. Although the extent of dengue activity in Brazil is higher than that of Venezuela, the risk of introducing dengue from Brazil to Madeira is lower because of the lower overall interconnectivity via air travel between Brazil and Madeira. As the outbreak in Madeira was first reported in October 2012 [27], taking the extrinsic and intrinsic incubation time of the Aedes mosquitoes into account, the most likely time of importation into Madeira would have been between July to September 2012. Using the monthly index for July, August and September 2012, the importation index for Venezuela is seven times higher during this period than that for Brazil. This is because at this time of the year Venezuela has higher dengue activity than Brazil; dengue is seasonal in most dengue-endemic countries. Our findings, based on the importation index, suggest that Venezuela is the most likely source of importation of dengue to Madeira in late summer 2012, just before the outbreak's first reported case. 


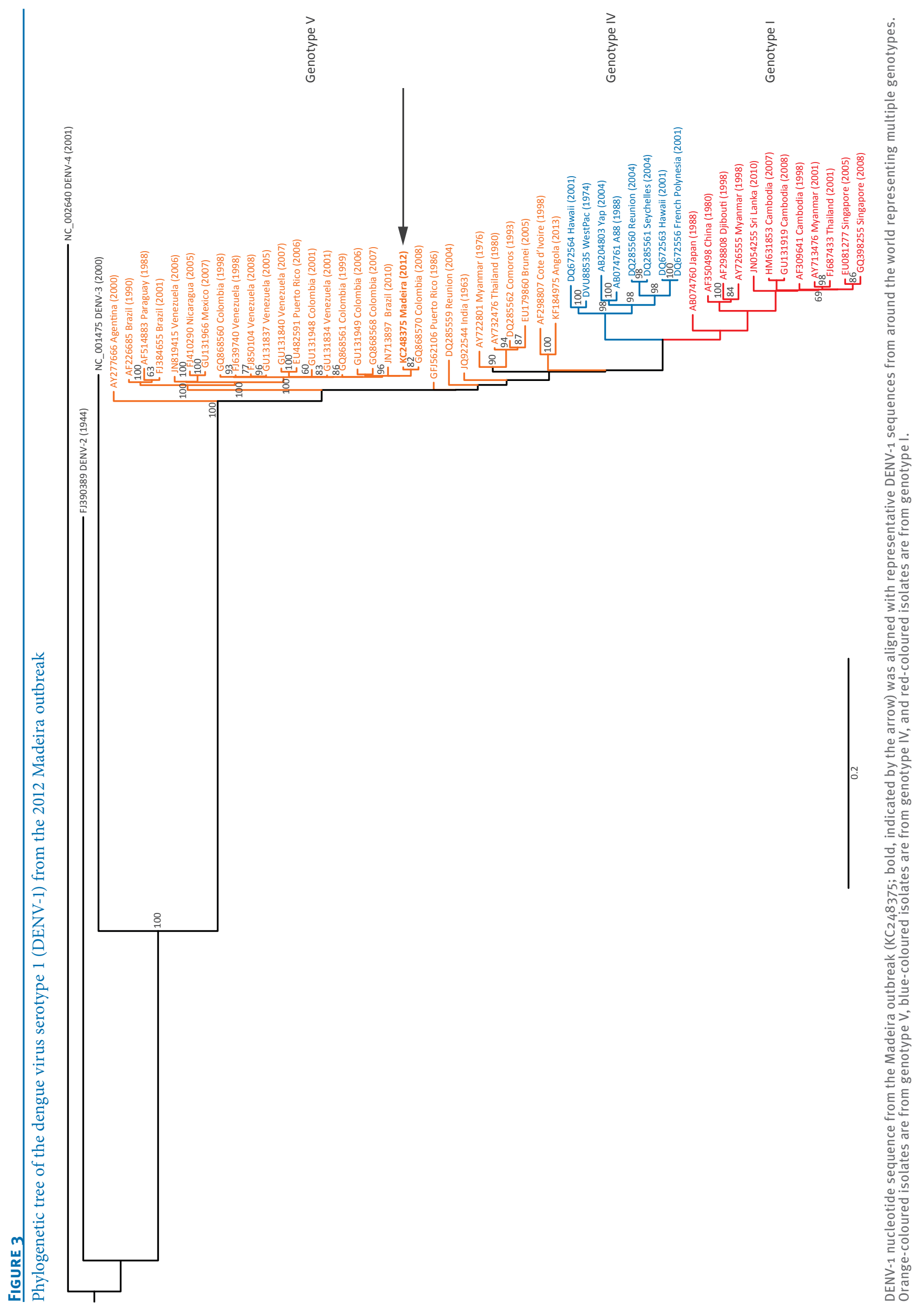


Annotating existing dengue sequences with GenBank further strengthens this conclusion. The 494 base pair sequence used for this analysis is highly related to South American dengue isolates from Colombia, Brazil and Venezuela, all neighbouring countries in South America. Analysis of NS5 and CprM partial sequences derived from one of the first cases by a Portuguese group and their preliminary phylogenetic analysis based on CprM nucleotide sequences also identified the virus to be related to viruses circulating in Latin America, more specifically from Venezuela and Colombia and the Roraima region in northern Brazil [27]. This finding is similar to that reached by sequencing done by Huhtamo's group based on a Finnish traveller from Madeira [48]. It should be noted that a different region of the DENV-1 genome was used for this analysis than was used by Huhtamo (C-prM instead of E).

This study has the following limitations. The first is that the importation index depends on the dengue activity in the country of origin; however underreporting and high variation between the notification rates of countries to WHO is likely, hence the true probability of importation is likely to be higher than reported in this analysis. Recent estimates of dengue incidence are several-fold higher than those reported by WHO [3]. The second limitation is that incidence data from Africa are lacking, and so we were not able to calculate reliable importation indices for most dengue-endemic countries from Africa. Furthermore, we do not know about undocumented population movements, for example via illegal migration. Interconnectivity between Africa and Madeira by air travel is, however, not high. The strongest interconnectivity via air from an African country to Madeira was Angola. Angola saw a major dengue outbreak due to dengue virus serotype 1 in 2013, shortly after the 2012 Madeira outbreak. Sequencing from the 2013 Angola outbreak performed by our group showed that this outbreak was not closely related to the Madeira outbreak, and was more closely related to a long-term circulating strain from west Africa [49]. The third limitation is that we focused on introduction of dengue virus via air travel and did not account for cargo or cruise ships. However, due to the short incubation time, introduction via air travel is far more likely, and hence we feel justified in our approach. The fourth limitation is that we only used a simple formula. Seyler et al. have previously developed a more complex Monte Carlo model based on the number of viraemic person-days among air travellers arriving in the European Union (EU), taking into account the probability distributions based on quarterly incidences in endemic countries, passenger flow from endemic to EU countries, duration of viraemia, probability of being viraemic upon arrival, and distribution and period of vector activity in the EU [50]. Our primary objective was to explore the most likely origin of importation, not to quantify the risk of establishment of dengue or the extent of the resulting outbreak, and so a simple importation index was deemed sufficient. Because of these limitations, our importation index is only a crude estimate. The importation index is therefore best used to relatively rank the most probable country of origin rather than to quantify the probability and size of dengue outbreaks after the introduction.

In conclusion, dengue sequencing of the Madeira dengue virus points to a Colombian, Venezuelan or Brazilian origin for the Madeira outbreak. The importation index suggests that Venezuela is the most likely country of origin for the dengue outbreak in Madeira in 2012. We propose that the importation index is a simple new additional tool that may aid in identifying and anticipating the most probable country of origin for importation of dengue into currently non-endemic countries.

Authors' contributions

AWS and JR had the study idea; AWS coordinated the analyses and wrote the manuscript. JR, AWS and KK developed the index; MQ and JL-H analysed the data on seasonality; MQ and KK obtained the data for the calculations of the importation index; MQ created the Table and Figure 2; OS created Figure 3; OS and LF analysed existing GenBanks; KK obtained and analysed all the air travel data. All co-authors contributed to the final manuscript.

\section{Conflict of interest}

None declared.

\section{References}

1. Wilder-Smith A, Gubler DJ. Geographic expansion of dengue: the impact of international travel. Med Clin North Am. 2008 Nov;92(6):1377-90, x. http://dx.doi.org/10.1016/j. mcna.2008.07.002

2. Dengue: guidelines for diagnosis, treatment, prevention and control. Geneva: World Health Organization; 2009.

3. Bhatt S, Gething PW, Brady OJ, Messina JP, Farlow AW, Moyes $\mathrm{CL}$, et al. The global distribution and burden of dengue. Nature. 25 Apr 2013;496(7446):504-7. http://dx.doi.org/10.1038/ nature12060

4. Gubler DJ. Dengue/dengue haemorrhagic fever: history and current status. Novartis Found Symp. 2006;277:3-16; discussion -22, 71-3, 251-3.

5. Gubler DJ. Dengue, urbanization and globalization: the unholy trinity of the 21(st) Century. Trop Med Health. 2011 Dec;39(4 Suppl):3-11. http://dx.doi.org/10.2149/tmh.2011-So5

6. Reiter P. Yellow fever and dengue: a threat to Europe? Euro Surveill. 11 Mar 2010;15(10):19509.

7. Wilder-Smith A, Schwartz E. Dengue in travelers. N Engl J Med. 2005;353(9):924-32. http://dx.doi.org/10.1056/NEJMra041927

8. Leder K, Torresi J, Brownstein JS, Wilson ME, Keystone JS, Barnett E, et al. Travel-associated illness trends and clusters, 2000-2010. Emerg Infect Dis. 2013;19(7):1049-73. http://dx.doi. org/10.3201/eid1907.121573

9. Schwartz E, Weld LH, Wilder-Smith A, von Sonnenburg F, Keystone JS, Kain KC, et al. Seasonality, annual trends, and characteristics of dengue among ill returned travelers, 19972006. Emerg Infect Dis. 2008;14(7):1081-8. http://dx.doi. org/10.3201/eid1407.071412

10. Leder K, Torresi J, Libman MD, Cramer JP, Castelli F, Schlagenhauf $P$, et al. GeoSentinel surveillance of illness in returned travelers, 2007-2011. Ann Intern Med. 19 Mar 2013;158(6):456-68. http://dx.doi. org/10.7326/0003-4819-158-6-201303190-00005

11. Sung V, O’Brien DP, Matchett E, Brown GV, Torresi J. Dengue fever in travelers returning from southeast Asia. J Travel Med. 2003;10(4):208-13. http://dx.doi. org $/ 10.2310 / 7060.2003 .40555$ 
12. Australian Government Department of Health and Ageing. National Notifiable Diseases Surveillance System. Number of notifications for all diseases by year, Australia, 1991 to 2010 and year-to-date notifications for 2011. [Accessed 25 November 2011]. Available from: http://www9.health.gov.au/cda/source/ rpt_2_sel.cfm

13. Napoli C, Salcuni P, Pompa MG, Declich S, Rizzo C. Estimated imported infections of Chikungunya and Dengue in Italy, 2008 to 2011. J Travel Med. 2012;19(5):294-7. http://dx.doi. org/10.1111/j.1708-8305.2012.00640.x

14. Jelinek T, Muhlberger N, Harms G, Corachan M, Grobusch MP, Knobloch J, et al. Epidemiology and clinical features of imported dengue fever in Europe: sentinel surveillance data from TropNetEurop. Clin Infect Dis. 2002;35(9):1047-52. http:// dx.doi.org/10.1086/342906

15. Schmidt-Chanasit J, Tenner-Racz K, Poppert D, Emmerich $P$, Frank C, Dinges C, et al. Fatal dengue hemorrhagic fever imported into Germany. Infection. 2012;40(4):441-3. http:// dx.doi.org/10.1007/s15010-011-0208-3

16. Heddini A, Janzon R, Linde A. Increased number of dengue cases in Swedish travellers to Thailand. Euro Surveill. 5 Feb 2009;14(5). pii: 19111.

17. Effler PV, Pang L, Kitsutani P, Vorndam V, Nakata M, Ayers T, et al. Dengue fever, Hawaii, 2001-2002. Emerg Infect Dis. 2005;11(5):742-9. http://dx.doi.org/10.3201/eid1105.1063 http://dx.doi.org/10.3201/eid1105.041063

18. Dengue fever at the U.S.-Mexico border, 1995-1996. MMWR Morb Mortal Wkly Rep. 1996;45(39):841-4.

19. Adalja AA, Sell TK, Bouri N, Franco C. Lessons learned during dengue outbreaks in the United States, 2001-2011. Emerg Infect Dis. 2012;18(4):608-14. http://dx.doi.org/10.3201/ eid1804.110968

20. Hafkin B, Kaplan JE, Reed C, Elliott LB, Fontaine R, Sather $\mathrm{GE}$, et al. Reintroduction of dengue fever into the continental United States. I. Dengue surveillance in Texas, 1980. Am J Trop Med Hyg. 1982;31(6):1222-8.

21. Gubler DJ. Dengue and dengue hemorrhagic fever. Clin Microbiol Rev. 1998;11(3):480-96.

22. La Ruche G, Souares Y, Armengaud A, Peloux-Petiot F, Delaunay P, Despres P, et al. First two autochthonous dengue virus infections in metropolitan France, September 2010. Euro Surveill. 30 Sep 2010;15(39):19676.

23. Gjenero-Margan I, Aleraj B, Krajcar D, Lesnikar V, Klobucar A, Pem-Novosel I, et al. Autochthonous dengue fever in Croatia, August-September 2010. Euro Surveill. 2011 Mar 3;16(9). pii: 19805 .

24. Tomasello D, Schlagenhauf P. Chikungunya and dengue autochthonous cases in Europe, 2007-2012. Travel Med Infect Dis. 2013;11(5):274-84. http://dx.doi.org/10.1016/j. tmaid.2013.07.006

25. Halstead SB, Papaevangelou G. Transmission of dengue 1 and 2 viruses in Greece in 1928. Am J Trop Med Hyg. $1980 ; 29(4): 635-7$

26. Frank C, Hohle M, Stark K, Lawrence J. More reasons to dread rain on vacation? Dengue fever in 42 German and United Kingdom Madeira tourists during autumn 2012. Euro Surveill. 4 Apr 2013;18(14):20446. http://dx.doi.org/10.2807/1560-7917. ES2013.18.14.20446

27. Alves MJ, Fernandes PL, Amaro F, Osorio H, Luz T, Parreira $P$, et al. Clinical presentation and laboratory findings for the first autochthonous cases of dengue fever in Madeira island, Portugal, October 2012. Euro Surveill. 7 Feb 2013;18(6). pii: 20398.

28. Tatem AJ, Huang Z, Das A, Qi Q, Roth J, Qiu Y. Air travel and vector-borne disease movement. Parasitology. 2012 Dec;139(14):1816-30. http://dx.doi.org/10.1017/ So031182012000352

29. The Bio.Diaspora Project Toronto [Accessed 24 April 2013]. Available from: http://www.biodiaspora.com

30. Khan K, Arino J, Hu W, Raposo P, Sears J, Calderon F, et al. Spread of a novel influenza $A\left(\mathrm{H}_{1} \mathrm{~N}_{1}\right)$ virus via global airline transportation. N Engl J Med. 2009 Jul 9;361(2):212-4. http:// dx.doi.org/10.1056/NEJMc0904559

31. Brady OJ, Gething PW, Bhatt S, Messina JP, Brownstein JS, Hoen AG, et al. Refining the global spatial limits of dengue virus transmission by evidence-based consensus. PLoS Negl Trop Dis. 2012;6(8):e1760.

32. WHO Pan American Health Organization (PAHO). Number of Reported Cases of Dengue and Figures for 2012 (to week noted by each country) Epidemiological Week / EW 52 (Updated 20 May 2013). PAHO: Washington, D.C.; 2013. [Accessed May 2013]. Available from: http://www.paho.org/hq/index. php?option=com_docman\&task=doc_download\&gid $=21641 \& \mathrm{It}$ emid=270\&lang $=$ en
33. WHO Regional Office for South-East Asia (SEARO). WHO SouthEast Asia Region: Reported Cases and Deaths of Dengue from 2003 to 2012. SEARO: New Delhi; 2013. [Accessed April 2013]. Available from: http://www.searo.who.int/entity/vector_ borne_tropical_diseases/data/graphs.pdf

34. Western Pacific Regional Office of the World Health Organization (WPRO). WPRO Dengue Situation Update, o8 January 2013. Manila: WPRO; 2013. [Accessed April 2013] Available from: http://www.wpro.who.int/emerging_diseases/ Dengue.Report.8Jan2013.pdf

35. Western Pacific Regional Office of the World Health Organization (WPRO). WPRO Dengue Situation Update, 22 January 2013. Manila: WPRO; 2013. [Accessed April 2013]. Available from: http://www.wpro.who.int/emerging_diseases/ Dengue.Report.22Jan2013rev.pdf

36. IndexMundi [Internet]. [Accessed April 2013]. Available from: www.indexmundi.com

37. DENGUE - Notificações registradas no Sistema de Informação de Agravos de Notificação [Accessed 25 May 2013]. Available from: http://dtr2004.saude.gov.br/sinanweb/tabnet/ dh?sinannet/dengue/bases/denguebrnet.de

38. Gobierno Bolivariano de Venezuela Ministerio del Poder Popular para la Salud. Dengue. Boletín Epidemiológico. 2012;(52):12. [Accessed 25 May 2013]. Available from: http:// www.mpps.gob.ve/index.php?option=com_phocadownload\&vi ew $=$ category $\& i d=31: 2012 \&$ Itemid $=915$

39. Katoh K, Misawa K, Kuma K, Miyata T. MAFFT: a novel method for rapid multiple sequence alignment based on fast Fourier transform. Nucleic Acids Res. 15 Jul 2002;30(14):3059-66. http://dx.doi.org/10.1093/nar/gkf436

40. Stamatakis A, Ludwig T, Meier H. RAxML-III: a fast program for maximum likelihood-based inference of large phylogenetic trees. Bioinformatics. 15 Feb 2005;21(4):456-63. http://dx.doi. org/10.1093/bioinformatics/bti191

41. Rambaut A. FigTree. 2012 [Accessed 1 October 2013]; Available from: http://tree.bio.ed.ac.uk/software/figtree/

42. Reiter P. Aedes albopictus and the world trade in used tires, 1988-1995: the shape of things to come? J Am Mosq Control Assoc. 1998;14(1):83-94.

43. Gibbons RV, Vaughn DW. Dengue: an escalating problem. BMJ. 29 June 2002;324(7353):1563-6. http://dx.doi.org/10.1136/ bmj.324.7353.1563

44. Seixas G, Salgueiro P, Silva AC, Campos M, Spenassatto C, et al. Aedes aegypti on Madeira Island (Portugal): genetic variation of a recently introduced dengue vector. Mem Inst Oswaldo Cruz. 2013;108 Suppl 1:3-10.

45. Margarita Y, Gracio AJ, Lencastre I, Silva A, Novo M, et al. First record of Aedes (Stegomyia) aegypti (Diptera, Culicidae) in Madeira Island- Portugal. Acta Parasitol Port. 2006;13:59-61.

46. Warrilow D, Northill JA, Pyke AT. Sources of dengue viruses imported into Queensland, Australia, 2002-2010. Emerg Infect Dis. 2012;18(11):1850-7. http://dx.doi.org/10.3201/ eid1811.120014

47. Wilder-Smith A, Ooi EE, Vasudevan SG, Gubler DJ. Update on dengue: epidemiology, virus evolution, antiviral drugs, and vaccine development. Curr Infect Dis Rep. 2010;12(3):157-64. http://dx.doi.org/10.1007/s11908-010-0102-7

48. Huhtamo E, Korhonen E, Vapalahti O. Imported dengue virus serotype 1 from Madeira to Finland 2012. Euro Surveill. 2013 Feb 21;18(8). pii: 20405.

49. Sessions OM, Khan K, Hou Y, Meltzer E, Quam M, Schwartz E, et al. Exploring the origin and potential for spread of the 2013 dengue outbreak in Luanda, Angola. Glob Health Action. 2 Aug 2013;6:21822.

50. Seyler T, Grandesso F, Le Strat Y, Tarantola A, Depoortere E. Assessing the risk of importing dengue and chikungunya viruses to the European Union. Epidemics. 2009 Sep;1(3):17584. http://dx.doi.org/10.1016/j.epidem.2009.06.003 